\title{
Codes Across Languages: On the Translation of Literary Code-switching
}

\begin{abstract}
The translation of bilingual literary texts may challenge a translator when s/he needs to transfer some embedded, foreign codes from a language other than the dominant language of the source text (ST) into the target text (TT). This study analyses the way in which code-switching (CS) is transferred into a TT, looking at the translation strategies for CS in a non-European ST into European and non-European target texts. The source language text is Hebrew with Arabic incorporated into the Hebrew text in different ways, most often using CS. The target texts in the study are in Arabic, English, German and Italian languages.

The main aim of this study is to show how code-switching in literary paradigms can be translated into a target text language, and to what extent the original structure of instances of CS is maintained, changed or even deleted in the target texts. The study compares four versions of target texts in Arabic, English, Italian and German, followed by an overview of how the same CS instances are transferred across different languages and cultures. Some problems and issues related to the transfer of instances of CS into the target texts are discussed in view of the typology of the CS strategy. The study concludes with an argument that a better understanding of literary CS terminology regarding both linguistic and creative features is necessary for a better translation of bilingual literary texts.
\end{abstract}

\section{Keywords:}

Bilingualism; Translation; Code-switching; Arabic; Hebrew; German; English; Italian. 


\section{Introduction}

Living in a globalized world, particularly in the period of post-colonialism, creates a context in which many bilingual authors choose to write "in between" languages and countries to express their cross-cultural experiences. Multilingualism in literature has become one of the most noticeable features of literary texts written by bilingual authors. Bilingual or multilingual authors make more deliberate choices in their writing than would a conscious bilingual do in a normal conversation. When a bilingual author selects lexical items from a language other than the dominant language of the literary work, s/he may turn to two different strategies: glossing and inserting. The former refers to an author's attempt to translate and explain foreign word(s) so as to be intelligible for the reader who does not share the author's linguistic and cultural background. The latter term refers to the author's deliberate insertion of words or sentences that reflect the author's linguistic and cultural background:

The technique of selective lexical fidelity which leaves some words untranslated in the text is a more widely used device for conveying the sense of cultural distinctiveness. Such a device not only acts to signify the difference between cultures, but also illustrates the importance of discourse in interpreting cultural concepts (Ashcroft et al. 2003: 62).

The insertion and use of foreign codes in written texts can be defined as instances of codeswitching (CS). CS is a feature that results from languages in contact and refers to the act of switching between two languages or linguistic varieties in a single spoken or written work. The study of translating bilingual literary texts is not new, and there is a considerable body of literature that deals with the question of transferring the embodied foreign codes in the source text (ST) to the target text (TT): (Franco Arcia 2012; Leena \& Janne 2015; Mezei 1998; Valdeón

2005; Nurmi 2016; Cincotta 1996; Pym 2004; Chan 2002; Wright 2010; Tobias 2015). The bulk 
of these studies primarily focuses on bilingualism and translation between European languages. This study, however, is concerned with the translation of CS in literary texts in non-European languages (the Semitic languages of Arabic and Hebrew) and how these instances of CS are transferred or translated into both Semitic and European languages. Additionally, comparing different CS translations of one literary text provides an informative method to reach conclusions on the most appropriate strategies for translating CS.

This study discusses four translations of a Hebrew novel written in 2005 by Eli Amir (2005). Amir is an Iraqi-Jewish author who immigrated to Israel from Baghdad, Iraq in the 1950s. He was born in Baghdad in 1937, and he arrived in Israel when he was still 13 years old. Amir started to write only in Hebrew, even though he preferred to study Arabic language and literature at the Hebrew University in Jerusalem. Reflecting on the way Hebrew and Arabic merged in his literary work Mafriah ha-yonim (Farewell Baghdad) (1992), Amir says: "When writing this Hebrew novel, I imagined myself listening in one ear to my father telling it to me in Arabic" (Snir 2005: 338). Amir's own experience in the a $^{\text {'abara }}{ }^{1}$ during the 1950s and the move to the kibbutz is tapped as experience in Amir's first and famous novel (1983). As a 'bicultural bilingual', Amir extensively inserts Arabic words and phrases (in Hebrew script) into his literary works. The Hebrew novel under investigation was published in 2005. The novel tells the love story of Nuri, an Iraqi Jew who immigrated to Israel, and Jasmine, a Palestinian, who fall in love

\footnotetext{
${ }^{1}$ The ma 'abara (Hebrew: מעברה) was a transit camp for the new Jewish refugees in Israel during the 1950s. It was as absorption camp, at which accommodation for the newcomers was provided mainly for those who arrived in Israel during the mass immigration of the Oriental Jews. see Naor (1986).
} 
in Jerusalem. The events of the novel took place shortly after 1967 war, a period which was filled with conflicts and problems between Arabs and Jews.

The four translated versions of the Hebrew source text consist of three target texts in European languages: English (2012) translated by Yael Lotan, ${ }^{2}$ German (2009) translated by Barbara Linner $^{3}$ and Italian (2008) translated by Alessandra Shomroni. ${ }^{4}$ The fourth version is an Arabic translation of the Hebrew novel (2007), translated by Hussein Sirag. ${ }^{5}$ Indeed, the Arabic translation is also important to the study at hand, because Arabic is the language of the embedded foreign codes in the source Hebrew text. This provides an excellent opportunity to compare the translation of instances of CS in target text languages from two perspectives: firstly, when translating into a target text whose language is the language of the embedded codes in the source text; and secondly, in the case of translating the same codes into a target language that is different from both the source text language and the language of the code-switching.

\footnotetext{
${ }^{2}$ Yael Lotan was a journalist and a Hebrew-English translator. She translated several Hebrew books into English, including Modern Hebrew Fiction by Gershon Shaked, and The Invention of the Jewish People by Shlomo Sand. She is also the author of the English novel Avishag. Toby Press, 2002.

${ }^{3}$ Barbara Linner is a Hebrew-German translator who translated into Germany many Hebrew works by famous Israeli writers, such as David Grossmann. She studied Judaism, Oriental studies and Southeast European history.

${ }^{4}$ Alessandra Shomroni was graduated from History and History of the Middle East at the University of Haifa. She has been working as a translator from Hebrew to Italian language since 1996. She has translated many literary works of well-known Israeli writers, such as Abraham Yehoshua and David Grossman.

${ }^{5}$ Hussein Sirag was an Egyptian well-known journalist, who was reporting on Israeli issues. He translated and supervised the translation of a number of Hebrew books into Arabic.
} 
The paper also shows how instances of literary CS are transferred to the target text language in light of the typology of literary CS as suggested by Ahmed (2016a), which is discussed in more detail in the following section of the paper.

\section{Translation strategies for literary code-switching}

\subsection{Code-switching}

The study of CS has been thoroughly researched in recent decades in linguistic studies (Lipski 1977, 1985; Muysken 2000; Pfaff 1976, 1979; Poplack 1980, 1981). Additional studies have looked at the functional and social aspects of code-switching (Auer 1998; Blom \& Gumperz 1972; Gumperz 1977; McClure 1981). The debate over the typology of CS is one of the principal issues of this bilingual phenomenon. There are two main broad linguistic forms of CS: intra- and inter-sentential CS (Poplack 1980). The difference between intra-sentential CS (also called alternational CS (Muysken 2000) and classical CS (Myers-Scotton 1993) and inter-sentential CS is the position where the switching occurs. If the switched word(s) is/are integrated inside a single sentence or clause, it is a case of intra-sentential CS. However, intersentential CS occurs within the boundaries of the sentence.

\subsection{CS and translation}

Translating texts that contain some instances of CS is not an easy task for many translators. The main reason is the fact that the use of CS in a source text reflects not only linguistic and sociolinguistic elements, but also carries an aesthetic and literary message for the reader. Therefore, the translator must work on several parameters simultaneously in the translation of such texts. One consideration concerns the stylistic features associated with using CS in literary 
texts. Another reason is the uniqueness of bilingual literary texts, where authorial creativity is influenced by the unique practices of bilingualism. One example would be giving the characters distinctive names that make explicit the bicultural and bilingual backgrounds of the novel's protagonists explicit. Another example is the productive use of bilingualism, which reflects the community around the characters in a realistic fictional text. Not only does bilingualism influence the word and sentence levels, but its influence extends throughout the literary work in a way that highlights its uniqueness: 'The question of bilingual utterances leads us to the case of the bilingual literary work in which the presence of two or more languages is an integral part of the text's overall significance' (Sarkonak \& Hodgson 1993: 17). Therefore, omitting or not representing the CS in the TT in an appropriate way violates the original style of the ST.

As the translation of literary texts with instances of CS is problematic, in recent decades a considerable number of scholars and translators have discussed the question of translating bilingual literary texts (Franco Arcia 2012; Chan 2002; Pym 2004; Cincotta 1996; Haywood et al. 2009; Venuti 1998). For instance, Cincotta (1996) presented four possible strategies for translating CS into the target text:

1. Make the target text monolingual;

2. Keep the transfer in the original source language;

3. Use slang or a colloquial variety of the main target language;

4. Put the instances of CS in another language or dialect that is different from both the source and target text languages. 
Cincotta (1996: 4) advocated the fourth solution for translating CS, concluding that: "The fourth solution, that of finding another language or dialect into which to translate the transfer, is certainly both the most satisfying as well as the most difficult. It is the most satisfying in that it keeps the code-switch and it is not limited to a particular linguistic register or geographical manifestation of the target language itself, but most importantly because it can respect the intention of the author himself when he chose to make a use of a linguistic transfer."

Franco Arica (2012) suggests a strategy for translating instances of CS to a TT. Franco Arica (2012: 78) modifies Cincotta's (1996: 2-3) second suggestion of keeping the CS in the original source text in the target text, adding that 'we adapt her suggestion by changing the order of the languages in the TT: what is expressed in the second source language (SL), Spanish, in the ST will be now expressed in the first SL and vice-versa'. He suggests the term "mirror-effect translation" for this strategy, which can be applied to certain cases of literary texts, when there are no "translation couplets" in the text, "since they already provide an explanation within the text of code switch' and 'only when the second SL of the ST is the principal TL [target language] of the TT'. This suggested method takes into consideration the stylistic influence of the CS in the ST and tries to find a solution for having a relatively similar effect on the target audience. The question arises, then: in what way is the target audience ready for such texts? And how can the cultural elements that are most strongly associated with the language of the embedded codes in the ST be maintained in the CS of another language in the TT?

With respect to the role of the reader, when receiving a literary text, one should consider the author's intention and reason for inserting such instances of CS into it. One of the main reasons 
that drive bilingual authors to use two languages in a single text is to reflect their bilingualism and biculturalism by using language as a literary and stylistic device (Ibhawaegbele \& Edokpayi 2012; Keller 1976; Kellman 2000). Accordingly, when the source text A is translated into a target text language $B$, in which $B$ is the language of the inserted code-switching instances in the source text $\mathrm{A}$, there would be no need to insert CS in a third language as suggested above by Franco (2012). Basically because the instances of CS are mainly associated with bilingualism and biculturalism, and would be revealed and resolved by the target audience. To give an example, a French translation of an English novel in which the source text has instances of French CS. In this case, the target audience is mainly French, and therefore the majority of the readers can access all CS instances incorporated into the target text. In other words, the target audience should also be considered when translating literary texts with instances of CS, as "target cultures" should also be considered in translation (Toury 2012).

On the other hand, in the case of translating a bilingual literary text into a language that differs from both the ST and CS languages, the target audience would have no connection to either language. Here the culture of the target audience is not the same as the culture associated with either the inserted codes in the ST or the ST language itself. In this case, it is most common to maintain the original instances of CS in the TT. The question arises, then, of how to keep the instances of CS in the TT without affecting the stylistic influence of using foreign codes in the literary text and without making the TT difficult to read for a monolingual target audience. To answer this question, it is important to consider the typology of literary CS in order to introduce a good, moderate solution for translating it. The following section presents a typology of literary CS, followed by a suggested approach to the translation of CS instances. 


\subsection{On the typology of literary code-switching}

Although CS in literary texts has distinct features, research on written code-switching has generally followed the typology applied to conversational code-switching (Callahan 2004; Ibhawaegbele \& Edokpayi 2012; Jonsson 2010, 2005; Montes-Alcala 2000, 2012; Torres 2007). This study analyses the typology of CS in literary texts as suggested by (Ahmed 2016a), in which literary CS can be categorized in according to two main types. The first is hard-access codeswitching (HA-CS), which refers to any code added by the author that does not belong to the dominant language of the text and may be expected to create difficulties for a reader who does not share the author's bilingual and bicultural linguistic background (an "outsider reader", or Out.R). ${ }^{6}$ This type includes both inter-sentential code-switching and intra-sentential code switching.

The second type is easy-access code-switching (EA-CS), which refers to the codes inserted by the author, who tries to elucidate these codes in order to make them decodable to the Out.R. EA-CS involves both direct translation and glossing. This terminology provides a supplementary and broader description of the action of inserting foreign codes in the text with an author's assistance so as to make the text less bilingual.

\footnotetext{
${ }^{6}$ The term HA-CS is relative. It also depends on the reader's linguistic background. Some readers can access both languages in the text and, therefore, there would be no HA-CS in the text for them. On the other hand, it is difficult to anticipate the linguistic ability of the readership. What we can observe, however, is the way in which such instances of CS are employed in the text.
} 
A considerable number of studies have looked into the translation of instances of CS in literary texts that are sometimes followed by direct translation, glossing or some explanation of the inserted foreign codes. These studies are concerned with the translation aspect of the codes. Gumperz (1982: 78) was among the earliest scholars who noticed the strategy of translating codeswitching at conversational level, which he defines as reiteration: 'Frequently a message in one code is repeated in the other code, either literally or in somewhat modified form. In some cases such repetitions may serve to clarify what is said, but often they simply amplify or emphasize a message'. This strategy of clarifying foreign codes at conversational level is also found in written code-switching

The terms used to describe the translated or glossed codes in the bilingual paradigm include reiteration (Gumperz 1982: 78), intratextual translation (Nurmi 2016: 233-235) and paraphrasing. ${ }^{7}$ For the purposes of the study at hand, the translation or glossing of the inserted codes in the source text is considered EA-CS. Although these terms are very important to understand the way that the code-switching is employed, the translational aspects of the terms are more interesting than their sociolinguistic features. This strategy of translation, repetition, reiteration or intratextual translation apparently has one aim: they are there to elucidate the inserted foreign codes, to make them accessible for as many readers or listeners as possible, and to maintain the multiple voices of the characters with their cultural bonds and backgrounds in the text. This has been done either by means of translation, glossing or by using footnotes. Without a

\footnotetext{
${ }^{7}$ Katariina and Aleksi (2015) discuss this issue in depth.
} 
doubt, the translational aspect of such codes is essential. However, the fact that they are still foreign codes cannot be ignored. Therefore, the typology of code-switching in literary texts must be generally divided into two main types: EA-CS and HA-CS. The following examples demonstrate the typology of CS in literary texts:

(1) 'Abu George, I need you here urgently.' Abu Nabil's voice was uncharacteristically hesitant. 'It's to do with the Governor.'

'I am coming,' he replied and replaced the receiver.

'But it's harb wadarb, battles and war, out there!' Um George protested.

(Amir 2012: 8)

(2) “Yahud, min Israil, believe me!" the senator insisted.

"Shu Israil, what are you talking about?" replied Abu George, pitying the delusional old man.

(Amir 2012: 4)

These two examples show the two main types of CS. In Example (1), there is a direct translation of the Arabic code-switching: (حرب وضرب - harb wadarb), which means "battles and war". Therefore, the embedded Arabic code-switching is easily accessible by a monolingual reader who has no linguistic knowledge of the Arabic term inserted in the text. In Example (2), however, no help is provided in the text to explain the incorporated Arabic CS (ئسرد من إئل - Yahud, min Israil), which means "Jews from Israel." Here, the inserted code may cause some difficulties for the monolingual reader who cannot access and understand such codes. 
A third type has also been proposed to apply to cultural patterns associated with the mother tongue: ambiguous-access code-switching (AA-CS). This can be associated, for instance, with some cases of word-for-word translation, interjections and the use of some character and place names. ${ }^{8}$ This study, however, takes into consideration only the first two cases of literary CS described above, HA-CS and EA-CS, in this investigation of translating instances of CS.

\subsection{A suggested approach when translating CS}

Due to the importance of representing the structure of source text CS in the TT as discussed above, this study suggests that the transferred instances of CS maintain the original structure of CS in the ST. Additionally, the study suggests that HA-CS remain the same in the TT, i.e. there should not be any translation of these codes in the main text, although a footnote can be provided. Also, it is suggested that HA-CS not to be omitted or replaced by a translation in the TT. Moreover, the structure of EA-CS is to be maintained as well in the TT without omitting the source text CS or changing its structure. The following examples (3) and (4) demonstrate these points:

(3) (Source Text, p. 12):

יא גודעאן, הוי, גיבורי החיל, יא מוג'הדין, הוי, לוחמי הג'יהאד.

\footnotetext{
${ }^{8}$ For information about AA-CS, see Ahmed (2016a).

${ }^{9}$ Instances of CS in the source and target texts are marked in bold by the author.
} 


\section{Target Text (English):}

ya guidan, O brave warriors, ya mujahedeen, O jihad fighters. (Amir 2012: 2-3)

\section{Target Text (Italian):}

ya jid'an, eroi dell'esercito, ya mujahidin, combattenti del Jihad. (Amir, 2008: 4)

\section{Target Text (German):}

o ihr Helden des Kampfes, o ihr Mudschaheddin. (Amir 2009: 10)

This example shows how the TT follows the original structure of the inserted CS in the ST. The Arabic EA-CS instances in the ST have been maintained in the English and Italian TTs. This was done by transferring the CS in italic Latin script, followed by a translation into the TT language. In the German TT, however, the Arabic codes have been omitted and replaced by a translation. The following example shows the transfer of HA-CS into the TTs:

(4) (Source Text, p. 21):

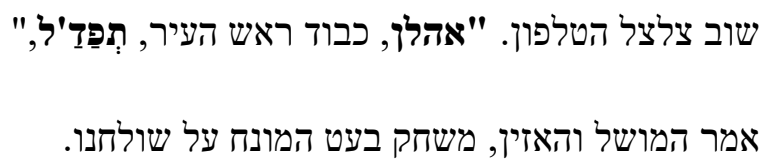

\section{Target Text (English):}

The phone rang again. "Ahlan, Mr Mayor go ahead.” As he listened, the governor fiddled with a pen on his desk. (Amir 2012: 12)

\section{Target Text (German):}

Wieder klingelte das Telefon. »Ahlan, verehrter Herr Bürgermeister, tafadal, bitte«, sagte der Gouverneur und lauschte, während er mit dem Stift spielte. (Amir 2009: 20) 


\section{Target Text (Italian):}

Il telefono squillò ancora. - Ahlan, signor sindaco, tafaddal -. Il governatore rimase in ascolto giocherellando nervosamente con una penna. (Amir 2008: 14)

As the examples clearly show (4), the Arabic HA-CS instances in the original text (Ahlan, tafadal) are not explained by the author in the ST. Therefore, they should also have been transferred as HA-CS into the TTs. Only the Italian TT maintained this structure. The English TT kept the first Arabic CS (Ahlan), while it ignored the second one and only provided an English translation ('go ahead'). The German TT did the same as the English TT with the first Arabic code. However, the second Arabic CS in the ST was maintained in the German TT, followed by a translation ('tafadal, bitte'). In doing this, the German TT turned the HA-CS into a case of EACS, deviating from the CS structure in the ST.

From the data analysed in this study, as the paper will show later, there are many cases of translation that changed the original construction of the embedded codes in the Hebrew source text. Therefore, it is easy to conclude that the translation of code-switching can cause problems. These seem to occur when the typology of the CS in written format is not understood.

\section{$3 \quad$ Arabic codes in four translations}

\subsection{The data}

The first two chapters of the source text were analysed linguistically. All of the instances of CS in the corpus were extracted and divided into the two main types of CS, HA-CS and EA-CS. The instances of CS were then inspected in the four translations. The study traced the instances of CS, whether the transferred CS cases were maintained in their original structure or not. All the cases 
of Arabic codes implemented in the corpus were manually extracted and analysed according to the typology of literary code-switching suggested by Ahmed (2016a). The study then traced the instances of Arabic codes in the corpus in the four translated versions.

A statistical study was conducted to show how often both types of CS were transferred into the four different translations, one of which was the CS language of the ST, Arabic. This numerical study shows the common and uncommon attributes of these translated versions. The study then concludes with a suggested approach to help in the translation or transference of instances of CS in literary texts.

\subsection{Discussion of the data}

The total number of HA-CS and EA-CS cases taken from the original Hebrew text are 41 and 31 respectively. ${ }^{10}$ All the CS cases are arranged in two tables (see appendices) according to their typology, HA-CS or EA-CS. To identify the transferred CS and determine whether the TT maintained the original structure of the inserted CS from the ST, the tables use (+) and (-).

The two tables below, together with the two appendices to this study, show that no sample from the four TTs of the Hebrew source text completely maintained the original structure of the foreign codes in the source text (i.e. Arabic codes employed in the Hebrew text). Although the corpus of the study is not large enough to draw a statistical conclusion about the way in which the CS structure is maintained in the TTs, it is generally possible to observe that the deviation from

${ }^{10}$ See the two appendixes with all of the CS extracts from the corpora of the study. 
the CS structure is more likely to occur with HA-CS cases than with EA-CS. Surprisingly enough, even the Arabic version, which is the language of the foreign codes in the source Hebrew text, contains some limited deviations from the original code-switching structure.

Table 1. Translation of Hard-Access Code-Switching

\begin{tabular}{|l|l|l|l|l|}
\hline $\begin{array}{l}\text { Follows the structure of the } \\
\text { inserted codes in the source text }\end{array}$ & English & German & Italian & Arabic \\
\hline$(+)$ & 25 & 21 & 25 & 40 \\
\hline$(-)$ & 16 & 20 & 16 & 1 \\
\hline
\end{tabular}

Table 2. Translation of Easy-Access Code-Switching

\begin{tabular}{|l|l|l|l|l|}
\hline $\begin{array}{l}\text { Follows the structure of inserted } \\
\text { codes in the source text }\end{array}$ & English & German & Italian & Arabic \\
\hline$(+)$ & 28 & 17 & 25 & 26 \\
\hline$(-)$ & 3 & 14 & 6 & 5 \\
\hline
\end{tabular}

However, before delving more deeply into a linguistic analysis and comparison of the four versions it is important to note some points. Firstly, this study is not concerned with the quality of the four translations, nor does it judge the different translations. Secondly, the paper serves as an extended and broader introduction to the typology of literary code-switching suggested by Ahmed (2016a), and the examples analysed in this study not only show the different ways of translating CS in literary texts but also present and expand upon the basic ideas about literary code-switching typology discussed earlier. The main aim, however, is to give an example of how code-switching in literary paradigms can be translated into a target text language and explore to what extent the original structure of the instances of CS has been maintained, changed or even 
removed in the target texts. These two major questions, among others, are discussed in the following sections.

\section{Translating code-switching between EA-CS and HA-CS}

\subsection{The translation of easy-access code-switching}

In their article about the interference between code-switching and translation, Kolehmainen and Skaffari (2015: 129) discuss the possible approaches that translators may take in translating the reiteration: "Translators may change the contents of the original message in many ways, for example in order to meet the expectations of the recipient or to adjust the new translated message to the new context. They may shorten the translated message from the original, provide a summary, or expand the message by adding new information; they may alter its viewpoints and even rewrite it completely and turn it into a very different message, making it difficult to recognize its relation to the original."

The approach in this citation about the transfer of CS into target texts is similar to the argument developed in the study at hand. As discussed above, this study considers cases of reiteration as easy-access code-switching (EA-CS).

This study provides evidence that some cases of EA-CS have been transferred to the TT in a way that turns them into HA-CS, i.e. the author of the origin Hebrew text puts the Hebrew translation directly after the embedded Arabic codes. However, some examples from the translated versions handle the Hebrew translation of the embedded Arabic codes in the ST as if they were Arabic foreign codes. In this case, the translator considers these translations a continuation of embedded 
EA-CS units. Consequently, this changes the construction of the original typology of the transferred CS into the TT; EA-CS become instances of complete HA-CS. The following example presents such a case:

(Source text, p. 16):

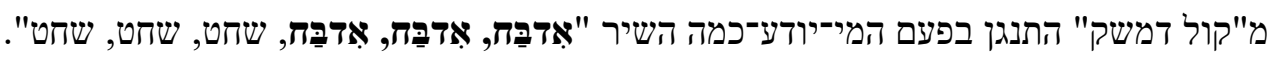

\section{Target text (English version):}

The Voice of Damascus broadcast yet again the song "Idbah, idbah, idbah" - "Slaughter, slaughter, slaughter". (Amir 2012: 6)

\section{Target text (Italian version):}

La Voce di Damasco transmetteva per l'ennesima volta la canzone Idbah, Idbah, Idbah, Shahit, Shahit, Shahit. (Amir 2008: 8)

In this example, Eli Amir originally uses the EA-CS strategy to make the Arabic code accessible to Israeli readers with no Arabic linguistic background. The Arabic verb idbaḥ (ادبح) is translated into Hebrew as shehat (שחט). Yet, the translator in the Italian version of the novel handles the Hebrew translation shehat in the ST as an Arabic code. He puts it in italics as if it were an instance of HA-CS, and he writes it phonetically incorrect as Shahit, instead of shehat. The translator does not provide any glossing for the embedded Arabic code in the TT. Thus, it appears in the Italian version as an instance of HA-CS. In this case, the translator turned a case of EA-CS into HA-CS, altering the original structure of the inserted CS in the ST. 
There are also some cases in which the translation violates the EA-CS structure in the source text. This is done by omitting the foreign codes in the target text. For instance, in the German version of the novel:

(6) (Source text, p. 17):

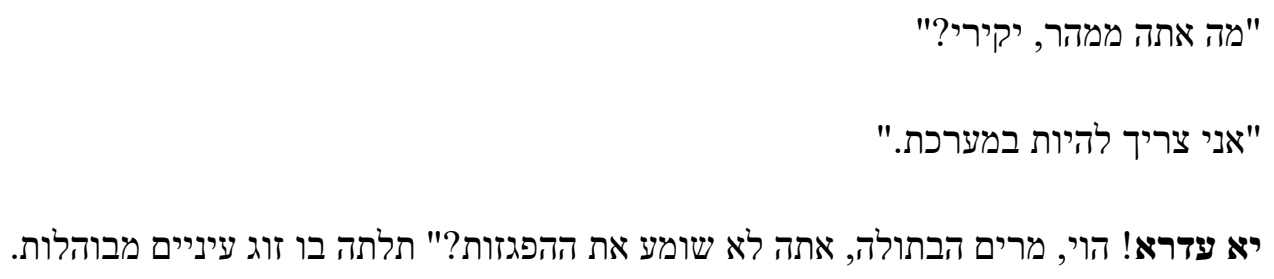

\section{Target Text (English):}

"Why you are rushing off, my dear?"

"I've got to be in the office."

"Ya Adhra ! O virgin Maryam, can't you hear the shelling?" She stared at him in alarm. (Amir 2012: 7)

\section{Target Text (German):}

»Was hast du es so eilig, mein Lieber?«

»Ich muss in die Redaktion.«

»O heilige Jungfrau Maria, hörst du die Detonationen nicht? « Sie starrte ihn erschrocken an. (Amir 2009: 15) 
In this example, the English TT maintains the original structure of the CS in the ST, that is the Arabic EA-CS in the ST yā 'adrā (יא עדרא) followed by a Hebrew translation by the author (, הוי) was transferred to the English TT by maintaining the Arabic codes written in italics: (' $\mathrm{Ya}$ Adhra') followed by an English translation ('O virgin Maryam') of the Hebrew translation by the author of the ST: (הוי, מרים הבתולה). On the other hand, the German TT ignores the EA-CS. Accordingly, only the Hebrew translation of the Arabic code $y \bar{a}{ }^{\prime} a d r \bar{a}$ (יא עדרא) in the ST has been transferred to the TT. This action violates the stylistic feature of the ST by making the TT read like a monolingual text. That is to say, using EA-CS adds various voices to the fictional characters in the TT. In addition, it can reflect the culture by including language varieties provided by using these instances of CS. Even in the Arabic translation of the target text, which is the language of the foreign codes employed in the source Hebrew text, there is some confusion between Hebrew (the dominant language of the source text) and Arabic (the language of the foreign codes in the source text). This confusion may occur because of the close similarity between the two Semitic languages ${ }^{11}$ in terms of many lexical items, as is the case with the word (maskin), which is found in both Arabic and Hebrew and has the same denotation:

(Source text, p. 22):

"אתם זוכרים איך לפני כמה ימים נאם ברדיו כדי לעודד את עמו, וגמגם מרוב פחד? מספין, מסכן! חה, חה..."

\footnotetext{
${ }^{11}$ For more examples about the confusion that may occur because of the similarity between Arabic and Hebrew in Iraqi Jewish fiction, see Ahmed (2016b).
} 


\section{Target Text (English)}

"You remember how a few days ago he addressed his people on the radio, and stammered with fright? Miskeen, poor thing! Ha ha...” (Amir 2012: 13)

\section{Target Text (Arabic)}

"تذكر ان كيف أنه قبل عدة أيام ألقى خطاباً في الإذاعة لتشجيع شعبه، وتلعثم من وطأة الخوف؟ مسكين، مسكين ! هاها ها ..." (Amir 2007: 24)

In the English TT, the EA-CS structure is maintained as it was in the ST. The translator was able to identify the Arabic CS, which was followed by a direct translation into Hebrew by the author in the ST. As mentioned above, the lexical similarity between Hebrew and Arabic did not confuse the translator of the English TT. Unlike the English version, the Arabic translation did not identify, apparently, the EA-CS case in the Hebrew ST. The Arabic TT may have treated the Arabic codes in the ST as an instance of a Hebrew word, which explains why the translation has two words instead of one.

EA-CS is also interesting in terms of the syntactic confusion that it might cause. Some translations contain borrowing using the TT language, in which a syntactic structure is applied to the foreign EA-CS from the ST. This is done by replacing the syntactic element of the foreign code in the ST with the equivalent syntactic feature in the TT language. For instance, the Arabic definite article in the Arabic code (al-Nakbe) is replaced by the Italian definite article la: 
(8) (Source text, p. 22):

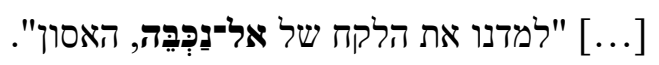

\section{Target Text (English)}

[...] "We have learned the lessons of al-Nakba, the catastrophe of 1948." (Amir 2012: 14)

\section{Target Text (Italian)}

Abbiamo imparato la lezione della Nakba, la catastrofe. (Amir 2008: 15)

It is clear from this example that instead of completely transferring the Arabic code al-Nakbe into the Italian TT, the translator replaced the Arabic definite article /al/ with the Italian definite article /la/. In other words, instead of translating it into (dell al-Nakbe) he transferred it in the TT to "della Nakbe".

There are also some problems associated with the transfer of the foreign codes in the ST into a TT when the language of the TT is the same as the foreign codes in the ST, e.g. the transfer of Arabic foreign codes in the Hebrew ST into an Arabic TT. One reason for this may be the language variations, dialects and sociolects associated with the CS language. Arabic, for instance, has many dialects and varieties across the Middle East: standard Arabic and a number of dialects in various countries. The different varieties of Arabic can also be problematic when transferring some instances of CS of Arabic codes into an Arabic TT:

(9) (Source text, pp. 23-24):

אפּו נביל העיף מבט בכרזה הצבעונית של קולנוע "אל-חמרא" וראה שמציגים את הסרט הרומנטי הישן "אל-ורבה אלפִיז'א", "השושן הלבן", של מחמד עבּד אל-וּהאבּ. 


\section{Target Text (English)}

Abu Nabil glanced at the colourful hoarding outside the al-Hamra cinema, displaying a scene from ${ }^{12}$ the old romantic film Al Warda al Baidha - The White Rose.

(Amir 2012: 15)

\section{Target Text (Arabic)}

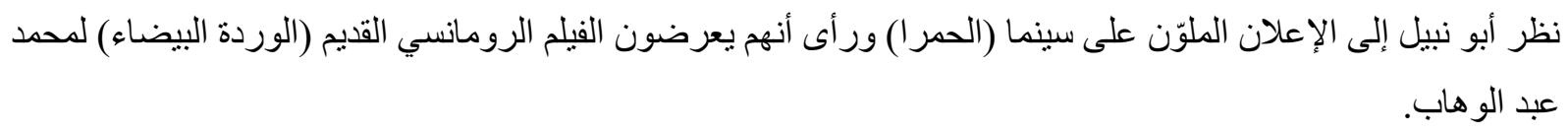

(Amir 2007: 25)

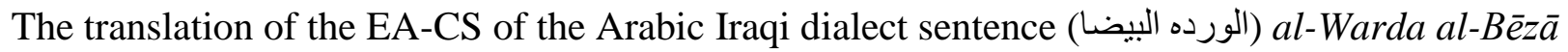
was copied into the target Arabic text in standard Arabic (الوردة البيضاء) al-Wardatu al-Baydā'. With regard to the general meaning of the transferred code into the TT, there is not much change here. However, with regard to stylistic and aesthetic reasons, the message in this code was not effectively delivered in the TT. The author's reason for inserting such Arabic codes into the Hebrew text was to reflect the various voices of the protagonists in his novel, which includes Palestinians, Jordanians and Mizrahi Jews (Jews from Arab and North African countries). By not reflecting these various dialects in the TT, an important stylistic feature is missing from the final translation product.

12 The underlined words are not in the Hebrew source text. 
In some cases, the transfer of the EA-CS in the source text into the target text does not adequately reflect the author's connotation or intention. This difficulty is likely to be found in the translation of embedded codes that contain idioms and folk sayings. The following example is characteristic:

\section{(10) (Source text, p.25):}

אבּו נבּיל לא הניח לו לסיים את המשפט, החווה בידו ואמר, "צלא עיפי ועלא ראסי, על עינַי ועל ראשי."

\section{Target Text (English)}

Abu Nabil raised his hand and said, "Ala ayni wala rasi, upon my eye and my head, Abu George. Leave it to me!” (Amir 2012: 15)

Before analysing the English translation, it is important to note that the original EA-CS structure of these idioms was done using a direct verbatim translation into Hebrew: (עלא עיני ועלא ראסי, על עינַי ועל ראשי. The translation of the Arabic codes into Hebrew by the author in the ST, apparently, was not sufficient to transmit the actual meaning of the Arabic vernacular idiom into, firstly, Hebrew for an Israeli reader who has no Arabic background and secondly, for an English reader. Therefore, a second translation or glossing was needed in the English translation after copying the same EA-CS structure into English: (Ala ayni wala rasi, upon my eye and my head, Abu George. Leave it to me!). Here, the translation comes with a glossing sentence that explains the verbatim translation of the Arabic original codes in the ST ('Leave it to me!'). Another strategy that has been applied to these types of codes is found in the German version, in which the first version did not copy the Arabic codes into the target text and instead used a free translation (Amir 2009: 24): 
»Ich übernehme die Verantwortung, die ganze Verantwortung.«

The Italian version maintained the original EA-CS structure, with the Arabic idiom transferred into the TT in italics in Latin script. The Italian translation of the Arabic idiom is provided directly after the CS sentence (Amir 2008: 17):

- 'Ala 'ayni wa- 'ala rasi. Non ti preoccupare, mi occuperò io di tutto. -

In summary, the translation of EA-CS is sometimes problematic. Although the embedded foreign code in the ST is accessible, as the author uses the dominant text language to clarify and explain the embedded instances of CS, transferring EA-CS into the TTs in this study deviates at some instances from the original EA-CS structure, which inserts instances of CS followed or surrounded by a translation or a glossing in the ST.

\subsection{The translation of hard-access code-switching}

When translating HA-CS, the potential to interfere on the part of the translator is substantially greater than when translating EA-CS. This is because translating EA-CS is likely to be easier for the translator if the author of the ST has provided the translation of the embedded code.

Moreover, the structure of the EA-CS is convenient for the translator with regard to transferring the CS into the TT.

The translation of HA-CS, on the other hand, is inconsistent when transferring these codes into the TT, as this study shows. These different methods alternate the original structure of HA-CS and its associated stylistic effects, both linguistic and literary. The translators in this study translated the HA-CS instances into the target language in several ways. Below is an analysis of how the translations of HA-CS were done: 


\section{(11) (Source text, p.15):}

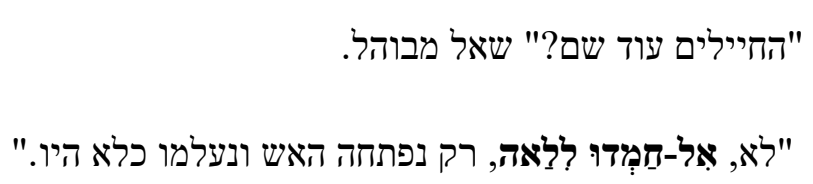

Target Text (English):

"Are the soldiers still there?" he asked anxiously.

"No, al-hamdu lillah, thank God, as soon as the firing began they vanished." (Amir 2012: 6)

In this example, the CS in the ST is incorporated into the text without any further glossing or translation by the author of the ST. In the TT, however, the translation maintains the Arabic transcription of the CS in italics (al-hamdu lillah), followed by an English translation ('thank God'). By adding this translation to the Arabic code-switching in the TT, the translation violates the original HA-CS structure in the ST. By doing this, the final TT product may contain many examples of HA-CS as if they are instances of EA-CS. Looking at the example (5) in the English TT, on the same page (Amir 2012: 6) the translation also includes the EA-CS ('Idbah, idbah, idbah' - 'Slaughter, slaughter, slaughter') in the same construction as when translating the HACS in this example ('al-hamdu lillah, thank God'). In other words, for an English reader, there would be no difference between the two translations. However, the two translations are not identical with regard to their CS typology in the ST; one is EA-CS while the other is HA-CS. The two other German and Italian TTs maintain the original structure of the HA-CS without any interference: 
Alhamdulillah. (Amir 2009: 14)

al-Hamdu li-llah. (Amir 2008: 8)

The way in which the HA-CS instances were transferred into the TTs in this study is not consistent. The sample analysed from the four TTs in the study, although quite small, shows various approaches with regard to the translation of HA-CS. Even in a single sentence with two cases of HA-CS, the translators' approaches to the two instances are not identical. For instance, in the following example, in which the ST contains two instances of HA-CS, the translator chooses to maintain the first CS as it appears in the ST, while the second HA-CS instance is omitted in the TT and replaced by a translation:

\section{(12) (Source text, p.21):}

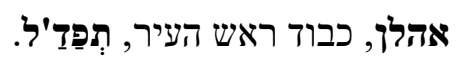

\section{Target Text (English):}

Ahlan, Mr Mayor go ahead. (Amir 2012: 12)

In this example, the translation first copied the HA-CS, the foreign Arabic code (أهلاً - Ahlan), directly into the target text without any glossing or translation of the code in the language of the TT. Yet, the translator did not copy the other Arabic code that comes at the end of the same sentence (تفضل - tefaddal), and instead chose to put the translation of the foreign HA-CS code into the TT language as ('go ahead'). In short, there is no consistency regarding the way in which the HA-CS was transferred into the TT.

Like the English TT, a similar approach toward translating the same CS in the ST is found in the German version. This time, the first Arabic HA-CS (Ahlan) is maintained in the original form in 
the TT, while the other HA-CS is turned into EA-CS by means of direct translation ('tafadal, bitte'):

Ahlan, verehrter Herr Bürgermeister, tafadal, bitte. (Amir 2009: 20)

Only the Italian TT maintains the original structure of the HA-CS as it was first embedded in the $\mathrm{ST}$; there is no interference on the part of the translator to elucidate these codes in the TT:

- Ahlan, signor sindaco, tafaddal -. (Amir 2008: 14)

In some CS cases, a good knowledge of Arabic colloquial terms is required to understand particular words or phrases and avoid the trap of phonetically or orthographically similar terms. For instance, there is some confusion distinguishing between yalla (hurry up), and ya Allah ('Oh God!') in the German version:

(13) (Source text, p.28):

יאללה, יאללה, טַח טַח טַח! צעק הילד ומחא כפיים.

\section{Target Text (German):}

»Ja Allah, ja Allah, ta-ta-tach!« schrie der Junge und klatschte in die Hände. (Amir 2009: 28)

Here the German translation handles yalla incorrectly, assuming that it is yā Allāh instead. But there is a difference between the two Arabic terms. The first is used to push someone to do something, while the second is a way of praying and calling to God.

Some CS cases that are associated with cultural symbols are particularly difficult to transfer into the TT. Insults are among these codes. The following serves as an example: 
(14) (Source text, p.37):

"מה אתה מחפס ברדיו של הערבים? כוּס אמם! ואני הסברתי והפצרתי, עד שנענה באי-רצון.

\section{Target Text (English):}

"What the hell do you want the Arabic station for? Screw them!" I explained and pleaded and finally he relented. (Amir 2012: 30)

\section{Target Text (German):}

»Was suchst du im Radio der Araber?« Und er fügte einen unflätigen Fluch hinzu. Ich eklärte und bettelte, bis er unwilling nachgab. (Amir 2008: 38)

\section{Target Text (Italian):}

Ma cosa cerchi nelle transmissioni delgi Arabi ? Che vadano all'inferno! - Io insistetti finché lui, di malavoglia, mi accontentò.

\section{Target Text (Arabic):}

$$
\text { (ما الذي تبحث عنه في راديو العرب ) فأخذت أشرح لله وأناثده إلى أن إستجاب عن غير رضا . }
$$

(Amir 2007: 37-38)

Although all the TTs maintain the structure of the HA-CS in many extracts in this study, ${ }^{13}$ in many ways, the HA-CS in this example, among others, was not transferred into any TTs as it was in the ST. Instead, the HA-CS was treated in diverse ways. The English and Italian versions use

\footnotetext{
${ }^{13}$ See the two appendices of CS translations.
} 
the equivalent terms to convey the Arabic CS in the ST message respectively: ('Screw them!') and ('Che vadano all'inferno!'). The German TT inserts a long sentence to "explain" the actions of the character in the conversation using this insult: ('Und er fügte einen unflätigen Fluch hinzu'). Finally, the fourth TT (Arabic version) ignores the HA-CS in the ST entirely.

\section{Conclusion}

The analysis of Arabic instances of CS in two chapters of a Hebrew novel to assess how these instances were translated or transferred into four target texts is extremely suggestive. The analysis raised a number of other related questions as well: how many cases of code-switching in its two principle types, hard-access code-switching (HA-CS) and easy-access code-switching (EA-CS), are maintained or modified in the target texts? How many cases of HA-CS in the source text (ST) were turned into EA-CS in the TTs and visa-versa? How many cases of both types of CS were omitted in the TTs, and why? The corpus of this study is not quite adequate to make an assertion based on a solid statistical analysis of these questions. However, the main beneficial result of this paper is that it shows how a small study of only a few pages in four translations can reveal quite different approaches towards translating CS, one of the most noteworthy features of literary texts written in a bilingual context.

The study demonstrates that a considerable number of CS cases were not properly transferred into the TTs. In other words, the original structure of the CS incorporated by the author of the ST was changed in the TT regarding both HA-CS and EA-CS. The original structure of the CS in the ST, as the study suggests, is very important from a stylistic point of view. Thus, it should not be neglected or aggressively modified in the TT. Indeed, the questions above raise another 
significant issue regarding the translation of CS, which is that the translation of CS should be consistent and reliable, and the translator should consider maintaining the original structure of the inserted CS in the ST when transferring it into the TT.

This study explains the different approaches to translating CS and the possible consequences of doing so for the final TT product. The terminology of CS in literary texts, therefore, is very important to understand the features of the phenomenon. Accordingly, a consistent translation can be achieved only when each type of the CS structure is understood and maintained in the TT. The study also takes into consideration the target audience and target culture.

The study argues that the original code-structure in the ST is a norm that a translator should adhere to when transferring this code-switching into the TT. Accordingly, the transfer of EA-CS into the TT should include both the original CS as it appears in the ST followed by the translation of this code into the language of the TT. Any other alteration of the CS structure in the ST is seen as a deviation from the norm. Of course, when a target text language is the same language as the CS in the ST, no transfer is required.

The same holds true for the transfer of HA-CS. In this case, the original structure of the CS in the ST contains instances of CS without any explanation or clarification in the ST for such codes. To maintain the original structure with this kind of CS, the translator needs to interfere to elucidate the instances of CS in the TT. The study suggests that the translator can only interfere after transferring the original CS into the TT. Moreover, this interference should not influence the main effect of HA-CS, which is to make the text more bilingual. The study suggests that the best method is to transfer the HA-CS into the TT without any interpretation by the translator in the 
main text. If so desired, the translator can use glossing in the footnotes to explain the inserted CS, taking into account the 'formal equivalent' notion defined by Nida (1964). By maintaining the original structure of the CS in the TT in this way, the linguistic and literary function of the embedded CS in the ST is well represented in the TT. At the same time, the TT becomes accessible to both insider and outsider readers.

\section{References}

Ahmed, Mohamed A. H. 2016a. Arabic Codes in Hebrew Texts: On the Typology of Literary Code-switching. Journal of Jewish Languages 4(2). 203-230.

Ahmed, Mohamed A. H. 2016b. Two Languages, One Text: Cultural Translation in Iraqi Jewish Fiction. In Arndt Engelhardt, Lutz Fiedler, Elisabeth Gallas, Natasha Gordinsky \& Philipp Graf (eds.), Ein Paradigma der Moderne: Jüdische Geschichte in Schlüsselbegriffen (V\&R Academic), 221-235. Gottingen: Vandenhoeck \& Ruprecht.

Amir, Eli. 1983. Tarnegol kapparot (Sifriyat ofakim 113). Tel Aviv.

Amir, Eli. 1992. Mafriah ha-yonim (Sifriyah la-‘am 387). Tel Aviv.

Amir, Eli. 2005. Yasmin (Sifriyah la-'am 535). Tel Aviv: Hotsa'at ‘Am ‘oved.

Amir, Eli. 2007. Jasmine. Al-Mansoura: Ibn Luqman Books.

Amir, Eli. 2008. Jasmine. Torino: Einaudi.

Amir, Eli. 2009. Jasmin (btb), 1st edn. München: btb.

Amir, Eli. 2012. Yasmine. London: Halban.

Ashcroft, Bill, Gareth Griffiths \& Helen. Tiffin. 2003. The Empire Writes Back: Theory and Practice in Post-Colonial Literatures, 2nd edn. London: Routledge. 
Auer, Peter. 1998. Code-Switching in Conversation: Language, Interaction and Identity. London, New York: Routledge.

Blom, Jan-Petter \& John J. Gumperz. 1972. Social Meaning in Linguistic Structure: CodeSwitching in Nerway. In John J. Gumperz \& Dell H. Hymes (eds.), The Ethnography of Communication (Directions in sociolinguistics), 407-434. New York, N.Y. [etc.]: Holt, Rinehart and Winston.

Callahan, Laura. 2004. Spanish/English Codeswitching in a Written Corpus (Studies in bilingualism). Amsterdam: John Benjamins Pub.

Chan, Leo T.-H. 2002. Translating Bilinguality. The Translator 8(1). 49-72.

Cincotta, Madeleine S. 1996. Naturalising Linguistic Aliens: The Translation of Code-Switching. Conference on Interpreting and Translation. http://files.eric.ed.gov/fulltext/ED404868.pdf. Franco Arcia, Ulises J. 2012. Translating multilingual texts: The case of "Strictly professional" in Killing me softly. Morir amando by author Francisco Ibáñez-Carrasco. Mutatis Mutandis 5(1). $65-85$.

Gumperz, John J. 1977. The Sociolinguistic Significance of Conversational Code-Switching. RELC Journal 8(2). 1-34.

Gumperz, John J. 1982. Conversational code switching. In John J. Gumperz (ed.), Discourse Strategies (Studies in Interactional Sociolinguistics), 59-99. Cambridge: Cambridge University Press.

Haywood, Louise M., Sándor G. J. Hervey \& Michael. Thompson. 2009. Thinking Spanish translation: A course in translation method Spanish to English. London: Routledge. 
Ibhawaegbele, Faith O. \& Justina. Edokpayi. 2012. Code-Switching and Code-Mixing as Stylistic Devices in Nigerian Prose Fiction: A Study of Three Nigerian Novels. Research on Humanities and Social Sciences 2(6). 12-19.

Jonsson, Carla. 2005. Code-Switching in Chicano Theater: Power, Identity and Style in Three Plays by Cherríe Moraga. Umeå: Institutionen för moderna språk, Umeå universitet.

Jonsson, Carla. 2010. Functions of Code-Switching in Bilingual Theater: An Analysis of Three Chicano Plays. Journal of Pragmatics 42(5). 1296-1310.

Katariina, Harjunpää \& Mäkilähde Aleksi. 2015. Reiteration: At the intersection of codeswitching and translation. Multilingua 35(2). 163-201.

Keller, Gary. 1976. Toward a Stylistic Analysis of Bilingual Texts. In Mary A. Beck (ed.), The Analysis of Hispanic Texts: Current Trends in Methodology : 1st York College Colloquium. New York: Bilingual Press.

Kellman, Steven G. 2000. The Translingual Imagination. Lincoln: University of Nebraska Press.

Leena, Kolehmainen \& Skaffari Janne. 2015. Multilingual practices in contemporary and historical contexts: Interfaces between code-switching and translation. Multilingua 35(2). $123-$ 135.

Lipski, John M. 1977. Code-Switching and the Problem of Bilingual Competence. In Michel Paradis (ed.), The fourth LACUS Forum. Columbia, S.C: Hornbeam Press.

Lipski, John M. 1985. Linguistic Aspects of Spanish-English Language Switching. Tempe, Ariz: Center for Latin American Studies, Arizona State University. 
McClure, Erica. 1981. Formal and Functional Aspects of the Code-Switched Discourse of Bilingual Children. In Richard P. Duran (ed.), Latino Language and Communicative Behavior, 69-94. Norwood, N.J: Ablex Pub. Corp.

Mezei, Kathy. 1998. Bilingualism and Translation in/of Michèle Lalonde's Speak White. The Translator 4(2). 229-247.

Montes-Alcala, Cecilia. 2000. Two Languages, one Pen: Socio-Pragmatic Functions in Written Spanish-English Code-Switching. Santa Barbara: University of California PhD Thesis.

Montes-Alcala, Cecilia. 2012. Code-Switching in US-Latino Novels. In Mark Sebba, Shahrzad Mahootian \& Carla Jonsson (eds.), Language Mixing and Code-Switching in Writing: Approaches to Mixed-Language Written Discourse (Routledge critical studies in multilingualism), 68-88. New York: Routledge.

Muysken, Pieter. 2000. Bilingual Speech: A Typology of Code-Mixing. Cambridge, UK, New York: Cambridge University Press.

Myers-Scotton, Carol. 1993. Duelling Languages: Grammatical Structure in Codeswitching. Oxford, Eng., New York: Clarendon Press; Oxford University Press.

Naor, Mordechay. 1986. 'Olim u-ma 'barot, 1948-1952. Yerushalayim: Yad Yitshak Ben-Tsevi.

Nida, Eugene A. 1964. Toward a Science of Translating. Leiden: E. J. Brill.

Nurmi, Arja. 2016. Minority voices in literary fiction: a case study of translating multilingual practices. Multilingua 35(2). 227-249.

Pfaff, Carol W. (ed.). 1976. Functional and Structural Constraints on Syntactic Variation in Code-Switching. 
Pfaff, Carol W. 1979. Constraints on Language Mixing: Intrasentential Code-Switching and Borrowing in Spanish/English. Language 55(2). 291-318.

Poplack, Shana. 1980. "Sometimes I'll Start a Sentence in Spanish Y TERMINO EN ESPAÑOL": Toward a Typology of Code-Switching. Linguistics 18(7/8). 581-618.

Poplack, Shana. 1981. Syntactic Structure and Social Function. In Richard P. Duran (ed.), Latino Language and Communicative Behavior, 169-184. Norwood, N.J: Ablex Pub. Corp.

Pym, Anthony. 2004. On the Pragmatics of Translating Multilingual Texts. The Journal of Specialised Translation(1). 14-28.

Sarkonak, Ralph \& Richard Hodgson (eds.). 1993. Writing ... in Stereo: Bilingualism in the Text. Providence, RI: Rhode Island School of Design.

Snir, Reuven. 2005. 'Arviyut, Yahadut, Tsiyonut: Ma'avak zehuyot bi-yetsiratam shel Yehude 'Irak. Yerushalayim: Yad Yitshak Ben-Tsevi.

Tobias, Shani. 2015. Tawada Yōko: Translating from the 'Poetic Ravine'. Japanese Studies 35(2). 169-183.

Torres, L. 2007. In the Contact Zone: Code-Switching Strategies by Latino/a Writers. MELUS 32(1). 75-96.

Toury, Gideon. 2012. The Nature and Role of Norms in Translation. In Lawrence Venuti (ed.), The translation studies reader, 3rd edn., 168-181. London, New York: Routledge.

Valdeón, Roberto A. 2005. Asymmetric representations of languages in contact: uses and translations of French and Spanish in Frasier. In Dirk. Delabastita \& Rainier. Grutman (eds.), Fictionalising translation and multilingualism, 279-294. Antwerpen: Hoger Instituut voor Vertalers \& Tolken, Hogeschool Antwerpen. 
Venuti, Lawrence. 1998. The scandals of translation: Towards an ethics of difference. London: Routledge.

Wright, Chantal. 2010. Exophony and Literary Translation: What it Means for the Translator when a Writer Adopts a New Language. Target, International Journal of Translation Studies 22(1). 22-39.

\section{Appendices}

The appendices contain the list of code-switching instances in the source text and the comparison of the translations of these codes in the target texts of the study. The CS extracts from the source text are arranged in two tables according to the main two types of literary code-switching: easyaccess code-switching (EA-CS) and hard-access code-switching (HA-CS). The two tables compare the translations of CS instances in the four target texts. Each CS occurrence is listed in the source text as well as in the four target texts with page number reference. The translated CS instances in the four target texts are marked with (+) and (-) indicating the way in which the translated CS in the target texts follow the structure of the inserted codes in the source text. 


\subsection{EA-CS translations}

\begin{tabular}{|c|c|c|c|c|}
\hline $\begin{array}{l}\text { EA-CS } \\
\text { Source Text }\end{array}$ & English & German & Italian & Arabic \\
\hline 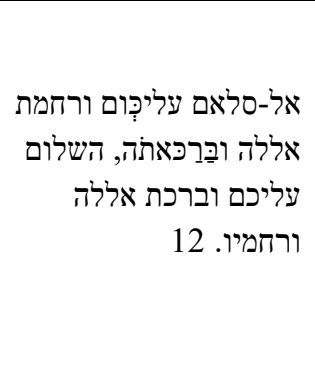 & $\begin{array}{l}+ \\
\text { As-salaamu aleikum } \\
\text { warahmatu'llah } \\
\text { wabarakatuh - peace } \\
\text { upon you and the } \\
\text { blessing and mercy of } \\
\text { Allah. } 2\end{array}$ & $\begin{array}{l}\text { - } \\
\text { As-salam aleikum, } \\
\text { Friede sei mit euch } \\
\text { und Allahs Segen } \\
\text { und Gnade. } 10\end{array}$ & $\begin{array}{l}+ \\
\text { Al-Salam 'alaykum } \\
\text { wa-rahmatu llahi wa- } \\
\text { barakatuhu. } \\
\text { salute a voi, dio vi } \\
\text { benedica e abbia } \\
\text { misericordia di voi. } 4\end{array}$ & جدان. \\
\hline הוחמיל, יא מודעאן, הוי, גיבורין הויה הוירי, & $\begin{array}{l}+ \\
\text { ya guidan, } \mathrm{O} \text { brave } \\
\text { warriors, } y a \\
\text { mujahedeen, } \mathrm{O} \text { jihad } \\
\text { fighters. } 2-3\end{array}$ & $\begin{array}{l}- \\
\text { o ihr Helden des } \\
\text { Kampfes, o ihr } \\
\text { Mudschaheddin. } 10\end{array}$ & $\begin{array}{l}+ \\
\text { ya jid 'an, eroi } \\
\text { dell'esercito, ya } \\
\text { mujahidin, } \\
\text { combattenti del } \\
\text { Jihad. } 4\end{array}$ & 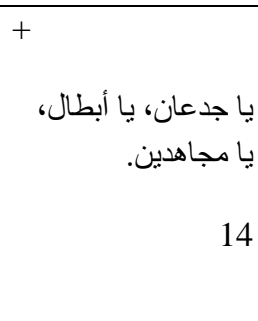 \\
\hline 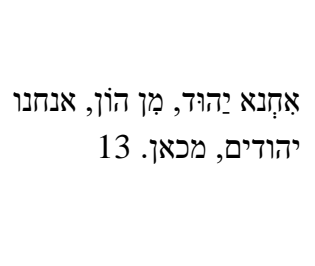 & $\begin{array}{l}+ \\
\text { Ihna yahud, min hon- } \\
\text { we are Jews, from } \\
\text { here. } 3\end{array}$ & $\begin{array}{l}+ \\
\text { Ihna jahud, min } \\
\text { hon, wir sind Juden, } \\
\text { von hier, von } \\
\text { Israel... } 11\end{array}$ & $\begin{array}{l}\text { - } \\
\text { - Ihna yahud, - disse, } \\
\text { - noi siamo Ebrei, di } \\
\text { qui, de Israele... } 5\end{array}$ & من إسر ائيل. من هون، \\
\hline שַג'רת אל-יהוד. 14 & $\begin{array}{l}+ \\
\text { shajarat al-yahud, a } \\
\text { "Jews' tree". } 5\end{array}$ & $\begin{array}{l}\text { - } \\
\text { Schadscharrat al- } \\
\text { Jahud, ein } \\
\text { ausladender } \\
\text { Eukalyptusbaum. } 13\end{array}$ & $\begin{array}{l}- \\
\text { Not found }\end{array}$ & شجرة اليهود. \\
\hline סֵ'מוד, סֵ'מוד, להחזיק 15 מעוד & $\begin{array}{l}+ \\
\text { Sumood, he said to } \\
\text { himself, hold out. } 6\end{array}$ & $\begin{array}{l}+ \\
\text { Sumud, sumud, } \\
\text { standhalten. } 14\end{array}$ & $\begin{array}{l}+ \\
\text { Sumud, sumud, } \\
\text { tenere duro. } 7\end{array}$ & أن يتمسك بالأرضد عليه. \\
\hline
\end{tabular}




\begin{tabular}{|c|c|c|c|c|}
\hline $\begin{array}{l}\text { EA-CS } \\
\text { Source Text }\end{array}$ & English & German & Italian & Arabic \\
\hline 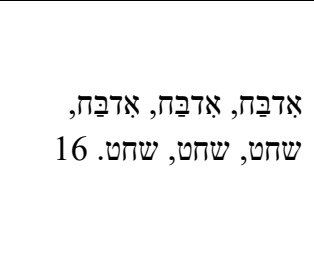 & $\begin{array}{l}+ \\
\text { "Idbah, idbah, idbah" } \\
\text { - "Slaughter, } \\
\text { slaughter, slaughter". } \\
6\end{array}$ & $\begin{array}{l}+ \\
\text { Ithbach, ithbach, } \\
\text { schlachten, } \\
\text { schlachten. } 14\end{array}$ & $\begin{array}{l}- \\
\text { Idbah, Idbah, Idbah, } \\
\text { Shahit, Shahit, } \\
\text { Shahit. } 8\end{array}$ & 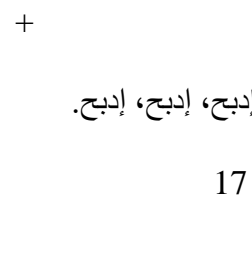 \\
\hline הבתולה. יא עדרא! הוי, מרים & $\begin{array}{l}+ \\
\text { Ya Adhra! O virgin } \\
\text { Maryam. } 7\end{array}$ & $\begin{array}{l}\text { - } \\
\text { O heilige Jungfrau } \\
\text { Maria. } 15\end{array}$ & $\begin{array}{l}+ \\
\text { Ya 'Adra'! Oh, } \\
\text { Maria Vergine. } 9\end{array}$ & يا عدرا !!. \\
\hline ומלחמות. ודבהּ, קרבות 18 ומדבי & $\begin{array}{l}+ \\
\text { harb wadarb, battles } \\
\text { and war. } 8\end{array}$ & $\begin{array}{l}+ \\
\text { Harb wa tharb, aber } \\
\text { es ist Krieg und } \\
\text { Verderben draußen. } \\
16\end{array}$ & $\begin{array}{l}+ \\
\text { Ma harb wa-darb. } \\
\text { ma fuori c'è la } \\
\text { guerra, si combatte. } \\
10\end{array}$ & حرب وضرب. \\
\hline עֵיבּּ, בושה !. 18 & $\begin{array}{l}- \\
\text { Shame. } 8\end{array}$ & $\begin{array}{l}+ \\
\text { Eib, welche } \\
\text { Schande! } 17\end{array}$ & $\begin{array}{l}+ \\
\text { 'Ayb, vergogna! } 10\end{array}$ & عيب !. \\
\hline אבבּוּנא אל-מַסיח, ישו 19 & $\begin{array}{l}+ \\
\text { Abuna el-Masih, Jesus } \\
\text { Father. } 10\end{array}$ & $\begin{array}{l}+ \\
\text { Abuna al-masih, } \\
\text { Cristus, unser Herr. } \\
18\end{array}$ & $\begin{array}{l}+ \\
\text { Abuna al-Masih, } \\
\text { Signore Iddio. } 11\end{array}$ & با با بانا المسيح. \\
\hline טובּאח אל-ח'יר, בוקר 19 & $\begin{array}{l}+ \\
\text { Sabah el khair, Abu } \\
\text { George, good } \\
\text { morning. } 10\end{array}$ & $\begin{array}{l}+ \\
\text { sabbah al-chair, } \\
\text { einen schönen guten } \\
\text { Morgen. } 18\end{array}$ & $\begin{array}{l}+ \\
\text { sabah al-kheir, } \\
\text { buongiorno. } 12\end{array}$ & صباح الخبر. \\
\hline
\end{tabular}




\begin{tabular}{|c|c|c|c|c|}
\hline $\begin{array}{l}\text { EA-CS } \\
\text { Source Text }\end{array}$ & English & German & Italian & Arabic \\
\hline מסכין. מסכן! 22 & $\begin{array}{l}+ \\
\text { Miskeen, poor thing!. } \\
13\end{array}$ & $\begin{array}{l}- \\
\text { Der arme Tropf!. } 21\end{array}$ & $\begin{array}{l}+ \\
\text { Miskin, poveretto!. } \\
15\end{array}$ & مسكين، مسكين. \\
\hline אל-נְכְבָּה, האסון. 22 & $\begin{array}{l}+ \\
\text { al-Nakba, the } \\
\text { catastrophe of } 1948 . \\
14\end{array}$ & $\begin{array}{l}+ \\
\text { al-Nakbe, der } \\
\text { Katastrophe. } 22\end{array}$ & $\begin{array}{l}+ \\
\text { della Nakba, la } \\
\text { catastrofe. } 15\end{array}$ & $\begin{array}{r}\text { النكبة. } \\
24\end{array}$ \\
\hline אותע-סנּאן, הסנטוא ח'יתאר, עַיאן וען & $\begin{array}{l}+ \\
\text { As-senator kharyar, } \\
\text { ayyan wata'ban - the } \\
\text { senator is old, sick and } \\
\text { weary. } 14\end{array}$ & $\begin{array}{l}\text { - } \\
\text { Der gute Senator ist } \\
\text { alt, krank und müde. } \\
23\end{array}$ & $\begin{array}{l}+ \\
\text { AL-Sinatur khitiar, } \\
\text { 'ayyan wa-ta'aban, il } \\
\text { senator è vechio, } \\
\text { malato e stanco. } 16\end{array}$ & 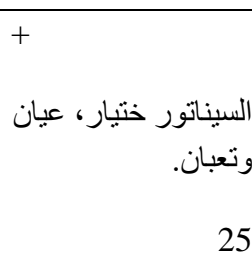 \\
\hline 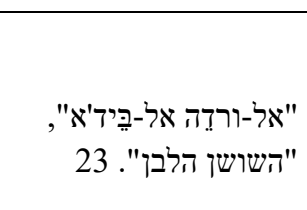 & $\begin{array}{l}+ \\
\text { Al Warda al Baidha- } \\
\text { The White Rose. } 15\end{array}$ & Die weiße Rose. 23 & N/A. 17 & الوردة البيضـاء. \\
\hline יא רית, הלוואי. 24 & $\begin{array}{l}+ \\
\text { Ya reit, that would be } \\
\text { nice. } 15\end{array}$ & Gebe es Gott. 24 & Not found & باريت. \\
\hline עינְי ועל ראשיני ועלא ראסי, על 24 & $\begin{array}{l}+ \\
\text { Ala ayni wala rasi, } \\
\text { upon my eye and my } \\
\text { head, Abu George. } \\
\text { Leave it to me!. } 15\end{array}$ & $\begin{array}{l}- \\
\text { "Ich übernehme die } \\
\text { Verantwortung, die } \\
\text { ganze } \\
\text { Verantwortung". } 24\end{array}$ & $\begin{array}{l}+ \\
- \text { 'Ala 'ayni wa-'ala } \\
\text { rasi. Non ti } \\
\text { preoccupare, mi } \\
\text { occuperò io di tutto. - } \\
17\end{array}$ & 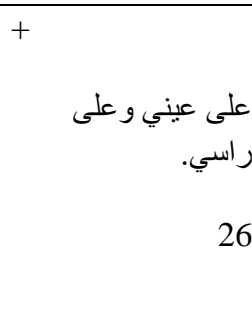 \\
\hline הבית. משאת אל-שריף, הרם של & $\begin{array}{l}+ \\
\text {...to the Haram al- } \\
\text { Sharif, the place that } \\
\text { the Jews called the } \\
\text { Temple Mount and }\end{array}$ & $\begin{array}{l}+ \\
\text { Haram asch-Scharif. } \\
\text { dem Tempelberg, } \\
\text { trugen, dem Object } \\
\text { der Begierde der } \\
\text { Juden. } 25\end{array}$ & $\begin{array}{l}+ \\
\text { Haram al-Sharif } \\
\text { risplendeva di fronte } \\
\text { a loro, elegante e } \\
\text { luminosa. } 19\end{array}$ & 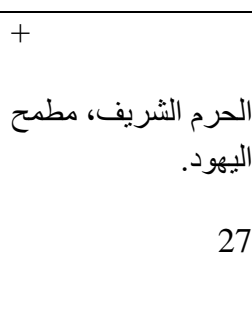 \\
\hline
\end{tabular}




\begin{tabular}{|c|c|c|c|c|}
\hline $\begin{array}{l}\text { EA-CS } \\
\text { Source Text }\end{array}$ & English & German & Italian & Arabic \\
\hline & $\begin{array}{l}\text { which they longed to } \\
\text { seize. } 16\end{array}$ & & & \\
\hline טוב.אח אל-ח'יר, בוקר & $\begin{array}{l}+ \\
\text { Sabah al-khair, good } \\
\text { morning. } 17\end{array}$ & $\begin{array}{l}+ \\
\text { Sabah al-cheir, } \\
\text { guten Morgen. } 25\end{array}$ & $\begin{array}{l}+ \\
\text { - Sabah al-kheir, } \\
\text { buongiorno. } 19\end{array}$ & صباح الخير. \\
\hline שכם. בּאב אל-עמוד, שער 25 & $\begin{array}{l}+ \\
\text { Bab el-Amoud, the } \\
\text { Damascus Gate. } 16\end{array}$ & $\begin{array}{l}+ \\
\text { Bab al-Amud, des } \\
\text { Damaskustors. } 25\end{array}$ & Not found & باب العمود. \\
\hline אל-בּלד, העיר. 26 & $\begin{array}{l}+ \\
\text { al-Balad, the city. } 17\end{array}$ & $\begin{array}{l}+ \\
\text { Al-balad, die Stadt. } \\
26\end{array}$ & $\begin{array}{l}+ \\
\text { al-Balad, la città. } 19\end{array}$ & المدينة. \\
\hline 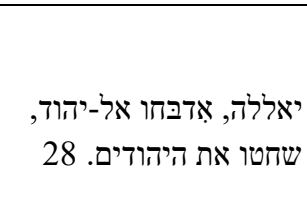 & $\begin{array}{l}+ \\
\text { Yalla, idbah al-yahud, } \\
\text { slaughter the Jews!. } 20\end{array}$ & $\begin{array}{l}\text { - } \\
\text { Ja Allah, sie } \\
\text { schlachten die } \\
\text { Juden. } 28\end{array}$ & $\begin{array}{l}+ \\
\text { - Yallah, Idbahu } \\
\text { alyahud, ammazzate } \\
\text { gli Ebrei. } 21\end{array}$ & يلال يللا إدبحوا اليهود. \\
\hline ולאד אברליס, בני השטן. & $\begin{array}{l}+ \\
\text { owlad iblis, sons of } \\
\text { devils. } 20\end{array}$ & $\begin{array}{l}- \\
\text { Hundesöhne und } \\
\text { Satansbraten. } 28\end{array}$ & $\begin{array}{l}+ \\
\text { Awlad Iblis Ablis, } \\
\text { figli di Satana. } 21\end{array}$ & أو لاد إبليس. \\
\hline עפַַארית, שדים. 28 & $\begin{array}{l}+ \\
\text { afaret, demons. } 20\end{array}$ & $\begin{array}{l}+ \\
\text { afarit, Teufel, } \\
\text { Dämonen. } 28\end{array}$ & $\begin{array}{l}+ \\
\text { Afarit, demoni!. } 21\end{array}$ & شياطين. \\
\hline העולמים. & $\begin{array}{l}+ \\
\text { Ya rab el-alamin, Lord } \\
\text { of the Universe. } 20\end{array}$ & O Herr der Welt. 29 & $\begin{array}{l}+ \\
\text { Ya Rabb al-'Alamin, } \\
\text { Dio onnipotente. } 22\end{array}$ & يا رب العالمين. \\
\hline
\end{tabular}




\begin{tabular}{|c|c|c|c|c|}
\hline EA-CS & English & German & Italian & Arabic \\
\hline מַסְר, מצרים. 39 & $\begin{array}{l}+ \\
\text { Misr, Egypt. } 32\end{array}$ & $\begin{array}{l}- \\
\text { Ägypten. } 41\end{array}$ & $\begin{array}{l}+ \\
\text { Masr, dell'Egitto. } 34\end{array}$ & - م مصر \\
\hline & & & & 40 \\
\hline אל-כראמה, הכבוד. 39 & $\begin{array}{l}+ \\
\text { al-karameh, honour. } \\
32\end{array}$ & $\begin{array}{l}+ \\
\text { al-Karama. der } \\
\text { Ehre. } 41\end{array}$ & $\begin{array}{l}+ \\
\text { al-Karama, l'onore. } \\
34\end{array}$ & لكر امة. \\
\hline האי-אסתעממאר, 39 & $\begin{array}{l}+ \\
\text { al-istimar, } \\
\text { imperialism. } 32\end{array}$ & $\begin{array}{l}- \\
\text { Imperialismus. } 41\end{array}$ & $\begin{array}{l}+ \\
\text { al-Isti'mar, } \\
\text { l'imperialismo. } 34\end{array}$ & لإستعمار. \\
\hline אל-עדו, האויב. 39-40 & not found & $\begin{array}{l}+ \\
\text { al-Adu, dem Feind. } \\
41\end{array}$ & $\begin{array}{l}+ \\
a l-A d u, \text { il nemico. } 34\end{array}$ & لعدو. \\
\hline אל-נס'ר, הניצחון. 40 & $\begin{array}{l}+ \\
\text { al-nasr, victory. } 32\end{array}$ & $\begin{array}{l}+ \\
\text { al-Nasr, dem Sieg. } \\
41\end{array}$ & $\begin{array}{l}+ \\
\text { al-Nasr, la vittoria. } \\
34\end{array}$ & ل النصر. 40 \\
\hline יא-סלאם, ישתבח שמו. & God in heaven. 37 & $\begin{array}{l}+ \\
\text { Ja salam, gepriesen } \\
\text { sei sein Name! } 45\end{array}$ & $\begin{array}{l}+ \\
\text { Ya salam, sia lodato } \\
\text { il Cielo. } 38\end{array}$ & با بام. \\
\hline
\end{tabular}




\subsection{HA-CS translations}

\begin{tabular}{|c|c|c|c|c|}
\hline HA-CS & English & German & Italian & Arabic \\
\hline אל-קוּדס. 11 & $\begin{array}{l}+ \\
\text { al-Quds, } 1\end{array}$ & $\begin{array}{l}\text { - } \\
\text { al-Quds al-Sharif, } \\
\text { der Heiligen Stadt. } 9\end{array}$ & $\begin{array}{l}+ \\
\text { al-Quds. } 3\end{array}$ & القسس. \\
\hline אל-קוּדס אל-שריף. 13 & $\begin{array}{l}+ \\
\text { al-Quds al-Sharif, } 3\end{array}$ & $\begin{array}{l}\text { - } \\
\text { al-Quds al-Sharif, } \\
\text { der Heiligen Stadt. } 11\end{array}$ & $\begin{array}{l}+ \\
\text { al-Quds al-Sharif, } 5\end{array}$ & القس الثريف. \\
\hline יהוד? מן אסראיל?. 13 & $\begin{array}{l}+ \\
\text { Yahud? Min Israil?. } \\
3\end{array}$ & $\begin{array}{l}- \\
\text { Juden? Von Israel?. } \\
11\end{array}$ & $\begin{array}{l}+ \\
\text { - Yahud? Min } \\
\text { Isra'il?- } 5\end{array}$ & ليهو د؟ من إسر ائيل؟ \\
\hline יהוד, מן אסראיל!. 14 & $\begin{array}{l}+ \\
\text { Yahud, min Israil. } 4\end{array}$ & $\begin{array}{l}\text { - } \\
\text { Ein Jude, von Israel! } \\
12\end{array}$ & $\begin{array}{l}+ \\
\text { Yehud, min Isra'il!. } \\
6\end{array}$ & يهود، من إسر ائيل! \\
\hline שוּ אסראיל. 14 & $\begin{array}{l}+ \\
\text { Shu Israil. } 4\end{array}$ & Was Israel. 12 & $\begin{array}{l}+ \\
\text { Shu Isra'il!. } 6\end{array}$ & شو إسر ائيل. \\
\hline סֵ'מוד, סֵ'מוד. 17 & $\begin{array}{l}+ \\
\text { Sumood, sumood. } 6\end{array}$ & $\begin{array}{l}+ \\
\text { Sumud, sumud. } 14\end{array}$ & $\begin{array}{l}+ \\
- \text { Sumud, sumud... -. } \\
7\end{array}$ & صمود.. صمود. \\
\hline אִל-חַמְדוּ לְלִאה. 15 & $\begin{array}{l}\text { - } \\
\text { Al-hamdu lillah, } \\
\text { thank God. } 6\end{array}$ & $\begin{array}{l}+ \\
\text { Alhamdulillah. } 14\end{array}$ & $\begin{array}{l}+ \\
\text { al-Hamdu li-llah. } 8\end{array}$ & الحمد لله. \\
\hline & - & - & - & + \\
\hline
\end{tabular}




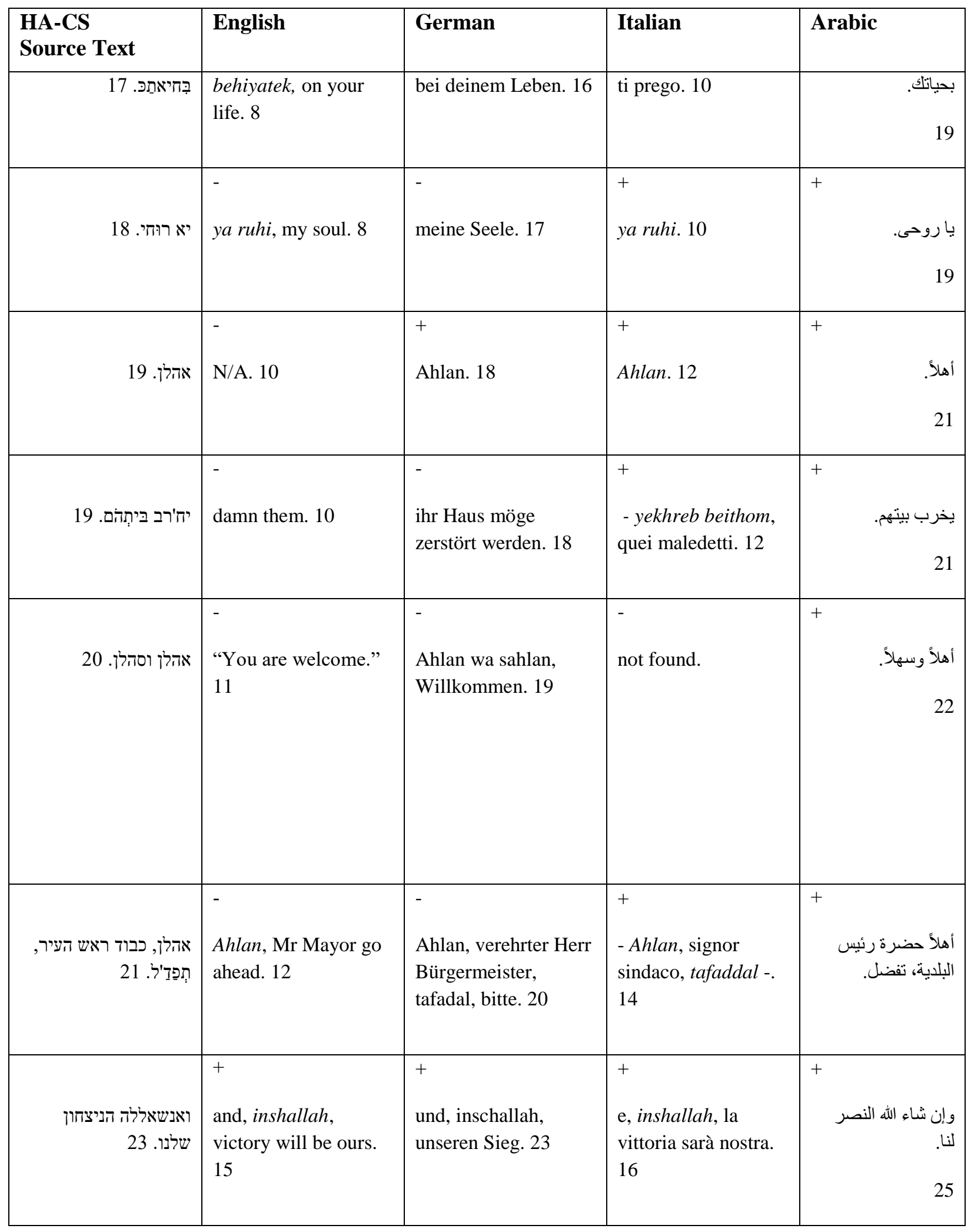




\begin{tabular}{|c|c|c|c|c|}
\hline $\begin{array}{l}\text { HA-CS } \\
\text { Source Text }\end{array}$ & English & German & Italian & Arabic \\
\hline איפת החולין של אל- 26 איפא. & $\begin{array}{l}+ \\
\text { the dome of the } \\
\text { mosque of al-Aqsa... } \\
17\end{array}$ & $\begin{array}{l}+ \\
\text { die Kuppel der al- } \\
\text { Aqsa Moschee. } 26\end{array}$ & $\begin{array}{l}+ \\
\text { la cupla grigia di al- } \\
\text { Aqsa. } 19\end{array}$ & قبة الأقصى. \\
\hline אלסבּאט. 26 יורים לבאבּ אל- & $\begin{array}{l}+ \\
\text { they're shooting at } \\
\text { Bab al-Asbat!. } 18\end{array}$ & $\begin{array}{l}+ \\
\text { sie schießen auf das } \\
\text { Bab al-Asbat!. } 26\end{array}$ & $\begin{array}{l}+ \\
\text { spraio su Bab al- } \\
\text { Asbat! } 20\end{array}$ & $\begin{array}{l}\text { إنهم يطلقون النار على الأسباط!. } \\
\text { باب }\end{array}$ \\
\hline לבפּאבּ אל-אלסרבּאט? לאר... & $\begin{array}{l}+ \\
\text { through Bab al- } \\
\text { Asbat? impossible, } \\
\text { it's too narrow. } 18\end{array}$ & $\begin{array}{l}+ \\
\text { vom Bab al-Asbat? } \\
\text { Das kann doch nicht } \\
\text { sein, das Tor ist zu } \\
\text { schmal. } 27\end{array}$ & $\begin{array}{l}+ \\
\text { Da Bab al-Asbat? } \\
\text { Non è possibile, la } \\
\text { porta è troppo } \\
\text { stretta. } 20\end{array}$ & من باب الأسباط؟ لا \\
\hline תולוי זו מלכודת, אנשאלה, & $\begin{array}{l}+ \\
\text { Maybe it's a booby- } \\
\text { trap, inshallah, that } \\
\text { will blow up in from } \\
\text { of them. } 19\end{array}$ & $\begin{array}{l}+ \\
\text { Vielleicht war das } \\
\text { eine Minenfalle, } \\
\text { inschallah, die ihnen } \\
\text { ins Gesicht fliegen } \\
\text { und sie aufhalten } \\
\text { würde. } 27\end{array}$ & $\begin{array}{l}+ \\
\text { Forsa era un } \\
\text { trabocchetto, era } \\
\text { piena di esplosivo. } \\
\text { Inshallah, che } \\
\text { esplodesse in facia a } \\
\text { quegli invasori e li } \\
\text { fermasse. } 20-21\end{array}$ & 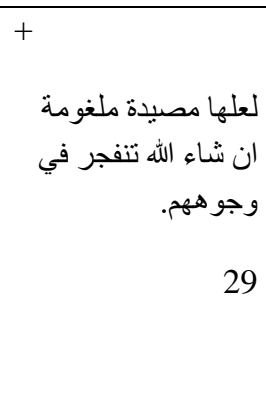 \\
\hline אללה, איפה אתה? 27 & $\begin{array}{l}+ \\
\text { Allah, where are } \\
\text { you? } 19\end{array}$ & $\begin{array}{l}+ \\
\text { Allah, wo bist du? } \\
\text { pp 27-28 }\end{array}$ & $\begin{array}{l}- \\
\text { Dio, dove sei?. } 21\end{array}$ & با الله ، أين أنت؟. \\
\hline \multirow[t]{2}{*}{ השבח לאללה. 27} & $\begin{array}{l}+ \\
\text { Thanks be to Allah. } \\
19\end{array}$ & $\begin{array}{l}+ \\
\text { Allah sei Dank. } 28\end{array}$ & $\begin{array}{l}\text { - } \\
\text { Grazie a Dio. } 21\end{array}$ & الحمد الله. \\
\hline & + & + & - & الله يكسر رقبتهم. \\
\hline
\end{tabular}




\begin{tabular}{|c|c|c|c|c|}
\hline $\begin{array}{l}\text { HA-CS } \\
\text { Source Text }\end{array}$ & English & German & Italian & Arabic \\
\hline מפרלה ישבור את. 27 & $\begin{array}{l}\text { Allah will break their } \\
\text { necks. } 19\end{array}$ & $\begin{array}{l}\text { Allah möge ihnen die } \\
\text { Gelenke brechen. } 28\end{array}$ & $\begin{array}{l}\text { - che Dio possa } \\
\text { spezzargli il collo- . } \\
21\end{array}$ & 29 \\
\hline 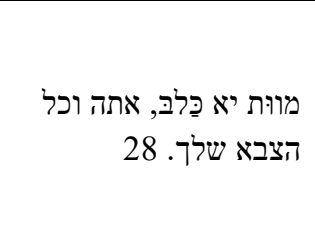 & $\begin{array}{l}\text { - } \\
\text { Die, dog! You and all } \\
\text { your army!. } 19\end{array}$ & $\begin{array}{l}\text { - } \\
\text { Tod, du Hund, dir } \\
\text { und deiner ganzen } \\
\text { Armee! } 28\end{array}$ & $\begin{array}{l}\text { - } \\
\text { Muori, bastardo, tu e } \\
\text { tutto il tuo esercito. } \\
21\end{array}$ & جيثتك. بـا كلب أنت وكل \\
\hline טַח! יאללה, יאללה, טַח טַח & $\begin{array}{l}\text { - } \\
\text { Yalla, Yalla! Go on! } \\
\text { Bang Bang Bang!. } 20\end{array}$ & $\begin{array}{l}+ \\
\text { Ja Allah, ja Allah, ta- } \\
\text { ta-tach!. } 28\end{array}$ & $\begin{array}{l}\text { Yallah, Yallah, bum } \\
\text { bum bum!. } 21\end{array}$ & طلاخا، يلا، طاخ طاخ \\
\hline ה"נַכּבַּהּ". 28 & $\begin{array}{l}\text { - } \\
\text { the Nakba, the } \\
\text { catastrophe, } 20\end{array}$ & $\begin{array}{l}\text { die Katastrophe, al- } \\
\text { Nakbe. } 29\end{array}$ & $\begin{array}{l}+ \\
\text { la Nakba. } 22\end{array}$ & بـ (النكبة). \\
\hline 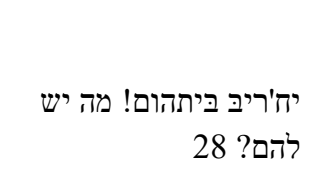 & $\begin{array}{l}\text { - } \\
\text { may their homes be } \\
\text { destroyed! } 20\end{array}$ & $\begin{array}{l}\text { - } \\
\text { Mochte ihr Haus } \\
\text { zerstört werden!. } 29\end{array}$ & $\begin{array}{l}\text { - } \\
\text { che le loro case } \\
\text { fossero distrutte! } 22\end{array}$ & يخرب بيتهم !. \\
\hline מלבהַּסּ. 33 & $\begin{array}{l}+ \\
\text { melabas. } 25\end{array}$ & $\begin{array}{l}\text { - } \\
\text { frische Brotringe. } 33\end{array}$ & $\begin{array}{l}- \\
\text { dolciumi. } 26\end{array}$ & 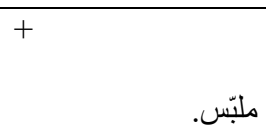 \\
\hline סַ'ות אל-ערבּ. 34 & $\begin{array}{l}+ \\
\text { Sawt al-Arab radio. } \\
27\end{array}$ & $\begin{array}{l}\text { Sa‘ut al-Arab, die } \\
\text { Stimme Arabiens. } 35\end{array}$ & $\begin{array}{l}+ \\
\text { Sawt al-Arab. } 28\end{array}$ & صوت العرب. \\
\hline & + & + & + & + \\
\hline
\end{tabular}




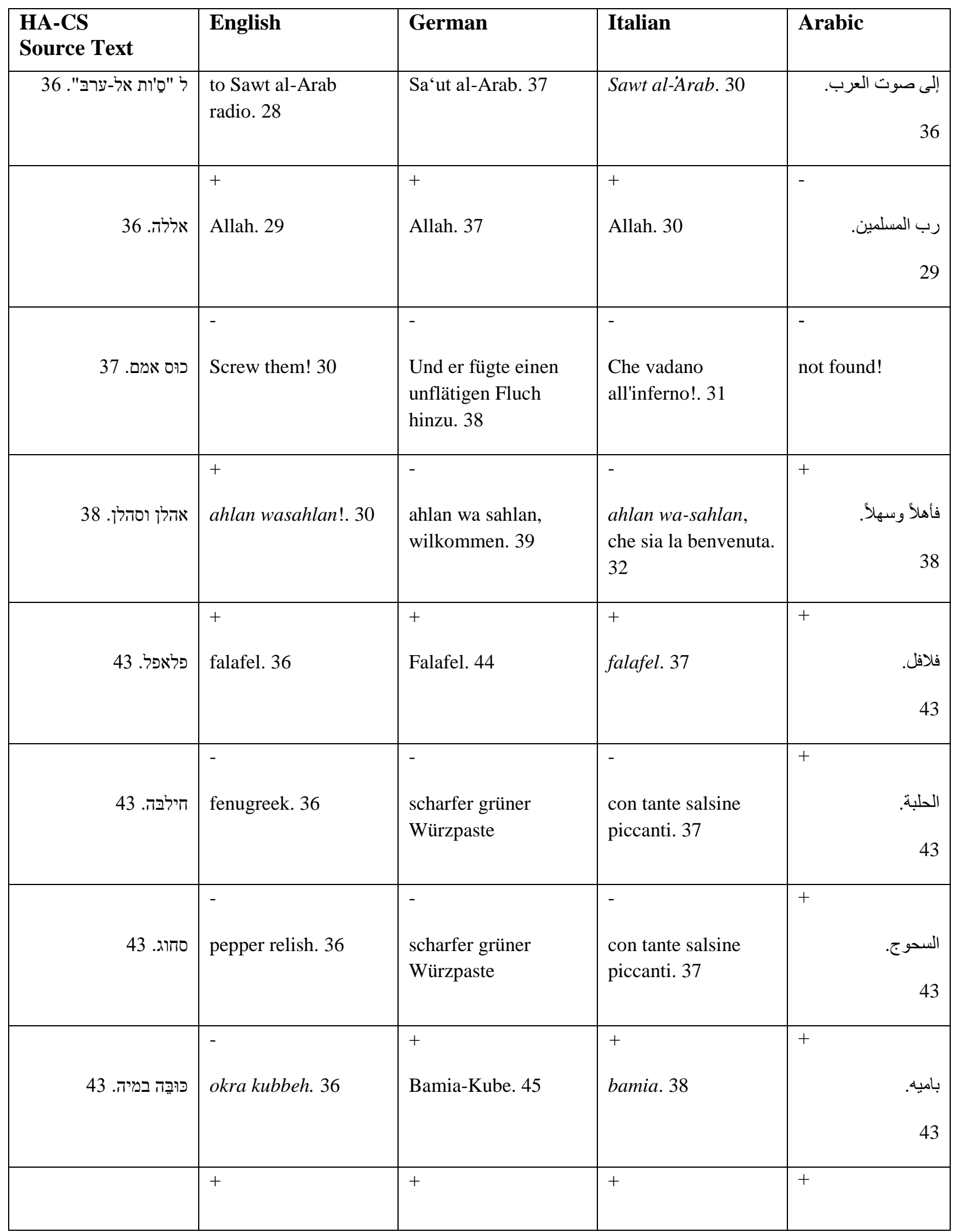




\begin{tabular}{|c|c|c|c|c|}
\hline $\begin{array}{l}\text { HA-CS } \\
\text { Source Text }\end{array}$ & English & German & Italian & Arabic \\
\hline טוב. שקעי ב"טרבּ" שכלו & $\begin{array}{l}\text { I plunged into a } \\
\text { blissful tarab. } 37\end{array}$ & $\begin{array}{l}\text { Für ein paar } \\
\text { Augenblicke versank } \\
\text { ich in Tarab. } 46\end{array}$ & $\begin{array}{l}\text { Per quiche secondo } \\
\text { sprofondai in un } \\
\text { meraviglioso tarab. } \\
39\end{array}$ & غرقت في "'طرب". \\
\hline מה זה "טרבּ". 44 & $\begin{array}{l}+ \\
\text { What is tarab. } 37\end{array}$ & $\begin{array}{l}+ \\
\text { Was ist "Tarab"? } 46\end{array}$ & $\begin{array}{l}+ \\
\text { Cos'è un } t a r b .39\end{array}$ & "الطرا الذي يعنيه \\
\hline יא מזרחן אפנדי. 44 & Mister Orientalist. 37 & $\begin{array}{l}+ \\
\text { O Effendi Orientalist. } \\
46\end{array}$ & $\begin{array}{l}- \\
\text { Singor orientalista. }\end{array}$ & مستشرق أفندي. \\
\hline "טרבּּ". 44 & $\begin{array}{l}+ \\
\text { tarab. } 37\end{array}$ & $\begin{array}{l}+ \\
\text { Tarab. } 46\end{array}$ & not found. & " الطرب". \\
\hline אל-ג'יהאד. 45 & $\begin{array}{l}+ \\
\text { Jihad. } 38\end{array}$ & Der Heilige Krieg. 46 & $\begin{array}{l}\text { - } \\
\text { il Jhad, la guerra } \\
\text { santa. } 39\end{array}$ & الجهاد. \\
\hline טרבּ. 45 & $\begin{array}{l}+ \\
\text { tarab. } 38\end{array}$ & $\begin{array}{l}+ \\
\text { Tarab. } 47\end{array}$ & $\begin{array}{l}+ \\
\text { tarab. } 40\end{array}$ & طرب. 45 \\
\hline
\end{tabular}

